\title{
Effect of Cold Storage on Composition and Properties of Grass Carp Muscle Proteins
}

\author{
Faxiang Wang, Yan Chen, Sai Chen, Xianghong Li, Jian Yu, Jianhui Wang and \\ Yongle Liu*
}

Hunan Provincial Engineering Technology Research Center of Aquatic Food Resources Processing, School of Chemical and Biological Engineering, Changsha University of Science and Technology, Changsha 410114, China

\section{A B S T RA C T}

The aim of present study was to evaluate the influence of cold storage on composition and properties of grass carp protein. The results show that muscle proteins of grass carp were degraded and underwent conformational changes when stored at $4{ }^{\circ} \mathrm{C}$, and significant changes of the proteins content, as shown by the SDS-PAGE fingerprint, was observed after 6 days of storage. Protein's surface hydrophobicity and total $\mathrm{SH}$ content increased during the first 4 days and then decreased gradually up to 10 days. The $\mathrm{Ca}^{2+}$ ATPase activity of protein decreased gradually during the storage period. The high MW proteins easily degraded during the cold storage, and the proteins with low MW were relatively stable but still gradually degraded. So the key time point for cold storage of grass carp is approximately 4-6 days.
\end{abstract}

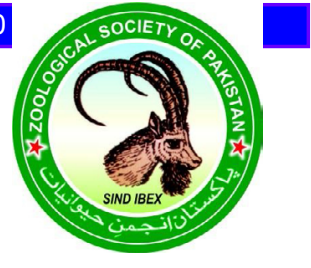

CrossMark

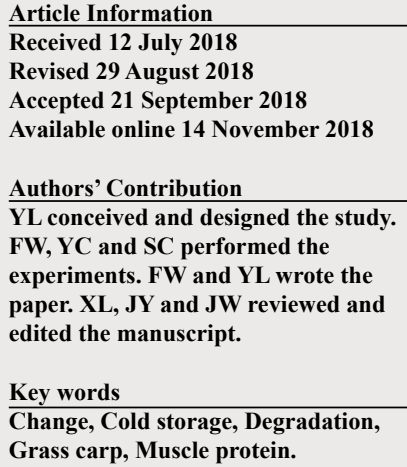

\section{INTRODUCTION}

G rass carp (Ctenopharyngodon idellus), one of the largest members of the family Cyprinidae, whose farming output already exceed 5.9 million tons on every year in China. The meat of grass carp has high nutritional values and moderate sale price, which is favored by consumers and manufacturers, and its consumption and output values tops all the freshwater fishes. However, the grass carp meat deteriorates easily during handling, distribution, processing and sale, which induces a huge waste of resources. Therefore, studies on quality changes during processing and storage are of great importance.

The quality of fish deterioration occurs mainly as results of autolysis (self-digestion) and microbial growth (Lone and Hans, 1996). Some researches about fish spoilage patterns and preservation technology have been performed (Kjaersgård and Jessen, 2003; Zhang et al., 2003; Reddish et al., 2008). At present, the problem of microbial growth could be controlled effectively by low temperature storage and some cold sterilization technologies. Some researches (Benjakul et al., 2003; Magdalena et al., 2007) have also found that degradation of fish muscle proteins during processing and storage are one of main causes of fish autolysis. For fish products, regardless of seafood or freshwater fish, the firmness of fish

\footnotetext{
Corresponding author: lyle19@163.com 0030-9923/2019/0001-0015 \$9.00/0

Copyright 2019 Zoological Society of Pakistan
}

is associated with the types of protein and their function (Moral et al., 2002; Godiksen et al., 2009), and myofibrillar protein is a structural protein that supports muscle performance. Some proteases from sarcoplasmic proteins, such as cathepsins, are correlated with fish muscle texture (Godiksen et al., 2009). Meanwhile, changes of these proteins can be reflected in the change of protein physicochemical properties, such as surface hydrophobicity, total SH content. Morever, degradation of fish proteins by cathepsins can easily result in textural changes and breakdown of muscle structure (Magdalena and Krzysztof, 2007). For example, Shi et al. (2012) demonstrated that fish proteins from silver carp disintegrate and produce peptides and amino acids, which disintegrate further and result in biogenic amines during storage. Thus, studies on the profiles of fish post-mortem proteolysis process could possibly help to prevent and/or control the deterioration of fish muscle quality.

Nowadays, the need to predict changes in the quality of fish meat in the process of refrigerating is attracting more and more attention from consumers (Hong et al., 2012). Until now, research on the concrete details and mechanisms of the proteome changes of grass carp during cold storage has been limited. Therefore, the specific objective of present study was to determine the changes in grass carp protein fractions during cold storage at $4^{\circ} \mathrm{C}$. This, in turn, would lead to a better understanding of the strategies for the preservation and improve the application or shelf life of freshwater fish. 


\section{MATERIALS AND METHODS}

\section{Sample preparation}

Fresh and alive grass carp (Ctenopharyngodon idellus) collected from local market was briefly reared in ice water mixture for $1 \mathrm{~h}$, then immediately washed, filleted, and packed in polyethylene bags. The packed fillets were stored in refrigerator $\left(4^{\circ} \mathrm{C}\right)$ and taken out at 0 , $2,4,6,8$ and 10 days of storage for analyses.

\section{Preparation of total and different types of protein fraction}

The total proteins of samples at different storage time were extracted as follows: $6 \mathrm{~g}$ fish meat paste was homogenized in $60 \mathrm{~mL}$ of extraction solution $(200 \mathrm{mmol} / \mathrm{L}$ $\mathrm{Na}_{2} \mathrm{HPO}_{4} / \mathrm{NaH}_{2} \mathrm{PO}_{4}, 2 \%$ (w/v) SDS, $100 \mathrm{mmol} / \mathrm{L}$ DTT, $\mathrm{pH}$ 7.4) by an Ultraturrax homogenizer (Omni THQ, USA) at $12000 \mathrm{r} / \mathrm{min}$ for $20 \mathrm{~s}$. The homogenate was then extracted twice using similar method above and protein concentration in the supernatant was measured by Lowry method (Ohnishi and Barra, 1978).

Different types of proteins (sarcoplasmic protein, myofibrillar protein and myostromin) were prepared by the method described by Chen and Hwang (2002). Concentrations of sarcoplasmic protein and myofibrillar protein were measured by Lowry method, and the myostromin concentration was assayed by Kjeldahl method. Each experiment was performed 3 times and the means were reported.

\section{Electrophoretic analysis of protein degradation}

For SDS-PAGE analysis, about $1 \mathrm{~g}$ of fish meat paste at different storage time was homogenized in $2 \mathrm{~mL}$ of extraction solution $[2 \%(\mathrm{w} / \mathrm{v})$ sodium dodecyl sulfate (SDS), $100 \mathrm{mmol} / \mathrm{L}$ dithiothreitol (DDT), $60 \mathrm{mmol} / \mathrm{L}$ Tris$\mathrm{HCl}, \mathrm{pH} 7.5$ ] for 30-60 s. The homogenate was added to $2 \times$ Laemmli loading buffer and homogenized for $30 \mathrm{~s}$, then boiled in a water bath for $3 \mathrm{~min}$. Electrophoretic analysis was then performed as the Niaz (2017) method using a $10 \% \mathrm{w} / \mathrm{v}$ gel concentration.

\section{Surface hydrophobicity}

Protein surface hydrophobicity was determined by the method of Benjakul et al. (1997) with minor modification. Prepared total protein in $0.01 \mathrm{~mol} / \mathrm{L}$ phosphate buffer, $\mathrm{pH} 7.0$ was diluted to $0.01,0.02,0.03,0.04,0.05 \%(\mathrm{w} / \mathrm{v})$ protein using the same buffer. The diluted protein (4 $\mathrm{mL}$ ) was stabilized and added with $10 \mathrm{~mL}$ of $0.08 \mathrm{~mol} / \mathrm{L}$ 8-anilino-1-naphthalenesulfonic acid (ANS) in 0.01 $\mathrm{mol} / \mathrm{L}$ phosphate buffer, $\mathrm{pH}$ 7.0. The relative fluorescence intensity of ANS-protein conjugates was measured using an PerkinElmer LS45 spectrofluorometer (American PerkinElmer Inc.) at excitation wavelength $365 \mathrm{~nm}$ and emission wavelength $480 \mathrm{~nm}$.

\section{Total SH analysis}

Total SH content was measured using a total mercapto (-SH) measurement kit (Nanjing Jiancheng Bioengineering Institute, Nanjing, China) according to the manufacturer's instructions.

\section{$\mathrm{Ca}^{2+}$-activated ATPase enzyme activity investigation}

$\mathrm{Ca}^{2+}$-activated ATPase enzyme ( $\mathrm{Ca}^{2+}$-ATPase) activity was determined for samples at different storage time and expressed as micrograms of inorganic phosphorous (Pi) per milligram protein per minute. $\mathrm{Ca}^{2+}$-ATPase activity was tested according to the method of Binsi et al. (2007).

\section{Statistical analysis}

All experiments were carried out for at least three times. Data were analyzed by analysis of standard deviations and variances using DPS V7.05 software (Tang and Zhang, 2013) All data sets were tested for normality, and duncan's multiple range test (DMRT) was used to determined statistical significance $(\mathrm{P}<0.05)$.

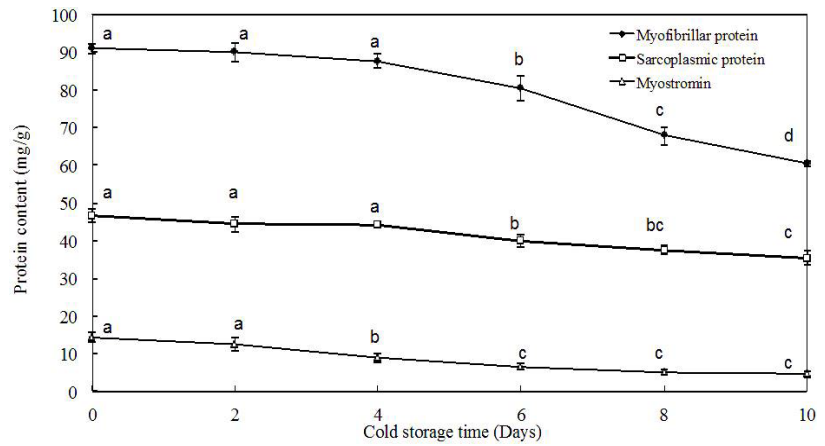

Fig. 1. Changes of relative content of three types of muscle proteins from Grass carp during cold storage $\left(4^{\circ} \mathrm{C}\right)$. All values are means $\pm \mathrm{SD}$; different letters indicate significant differences between storage times within the same group at $P<0.05$.

\section{RESULTS}

\section{Relative content of fish protein fractions}

Changes in relative content of three types of muscle protein (sarcoplasmic, myofibrillar protein and myostromin) from grass carp during cold storage $\left(4{ }^{\circ} \mathrm{C}\right)$ are shown in Figure 1. At the first four days, it could be well observed that relative contents of the sarcoplasmic and the myofibrillar protein decreased slightly but there were no significant differences. With the storage time prolonging, there was a remarkable decrease in the relative content of the myofibrillar protein, suggesting a dramatically degradation of this type of protein since or after 6 days cold storage. Compared to sarcoplasmic and 
myofibrillar protein, content change of the myostromin protein was mainly seen since or after 4 days cold storage. The decrease might be caused by the alterative solubility of part of this protein fraction, as variation with some fine structure of the thin filaments (Hamoir, 1955).

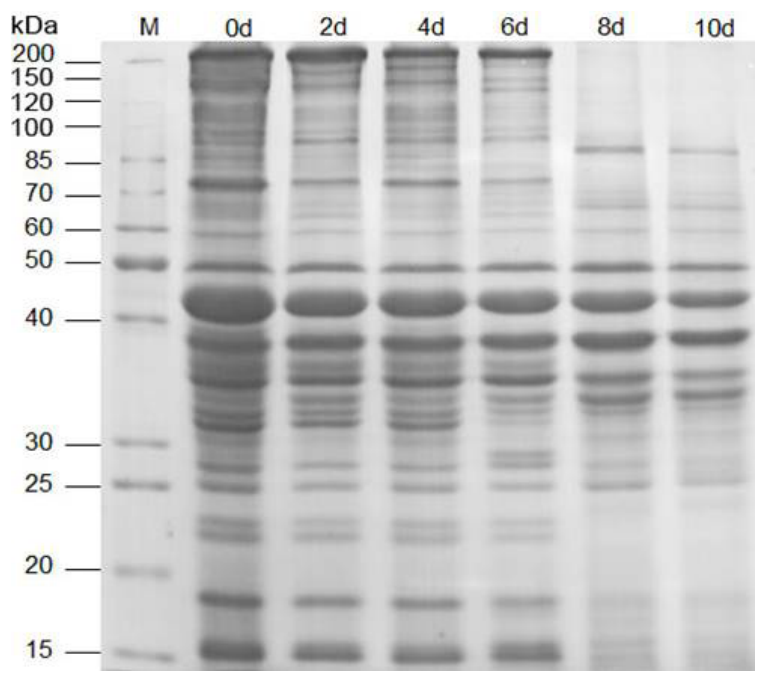

Fig. 2. SDS-PAGE patterns of muscle protein samples during cold storage $\left(4^{\circ} \mathrm{C}\right)$. Numbers designate storage days. M means high molecular weight standard.

\section{SDS-PAGE profiles}

The electrophoretic profiles for total proteins of samples at different storage time are presented in Figure 2. There was no significant difference observed in SDSPAGE patterns of 0, 2 and 4 day samples, which included about 30 protein bands. The signals of all protein bands were weakened to varying degrees, but obvious differences gradually emerged since or after cold storage for 6 days. Moreover, according to estimated molecular weight, bands of 212,17 and $15 \mathrm{kDa}$ completely disappeared in samples for the 8th and 10th day, but some bands with MW of 25 to $42 \mathrm{kDa}$ seemed to be relatively stable, because of no obvious protein signal change even at lane of the 10 d sample, which was consistent to the results reported else (Nelson, 1994; Sikorski and Kołakowska, 1995). Interestingly, a new $29 \mathrm{kDa}$ band in lanes $6 \mathrm{~d}$ and a new $90 \mathrm{kDa}$ band in lanes 8 and $10 \mathrm{~d}$ appeared, which could be explained as the degradated fragments from some high MW proteins.

The integrated optical density (IOD) of each protein band in all lanes was calculated in Table I, and some bands were assigned to respective proteins based on data from previous literatures (Jasra et al., 2001; Magdalena and Krzysztof, 2007). It could be clearly observed that the IOD of almost all protein bands were constantly reduced, and the variation tendency of IODs was in accordance with that of band signals in Figure 2.
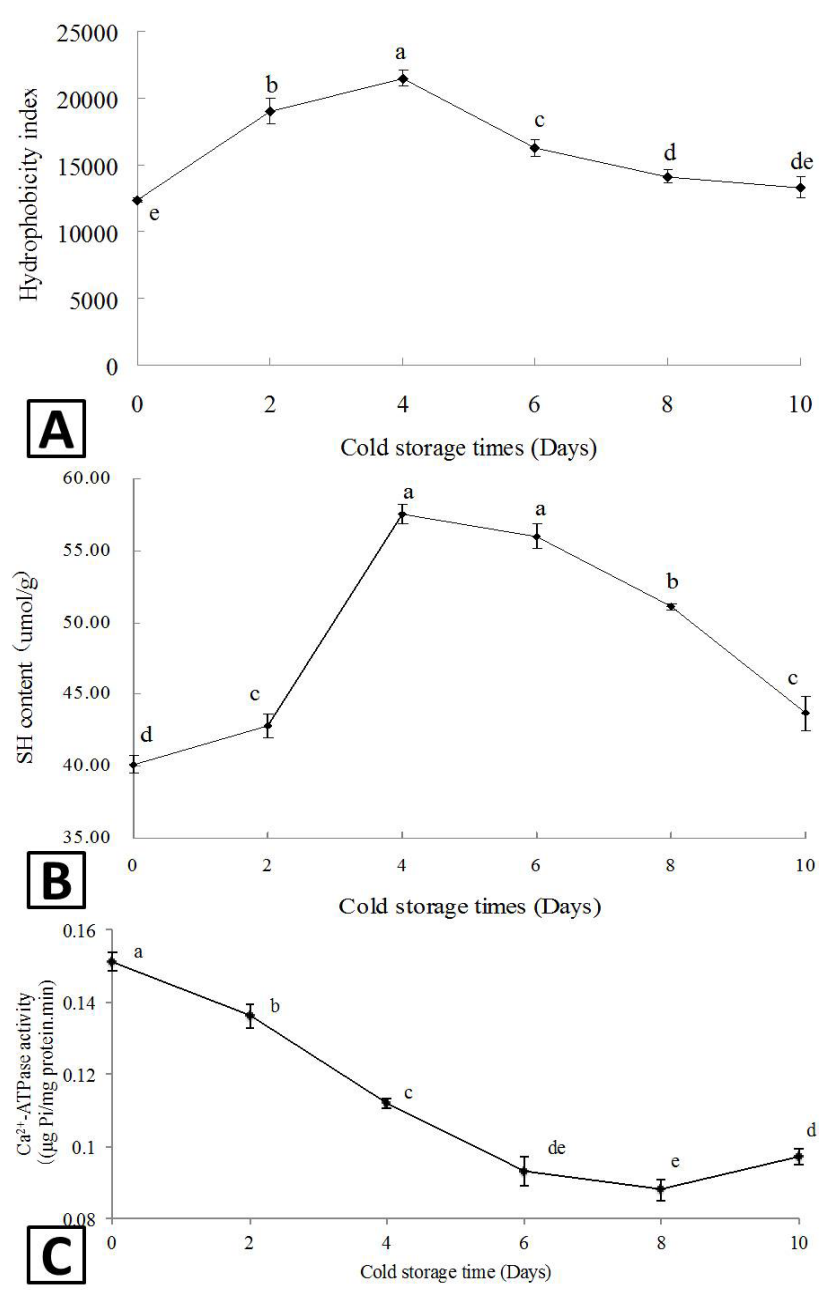

Fig. 3. Changes in surface hydrophobicity (A), total SH content (B) and $\mathrm{Ca}^{2+}$-ATPase activities (C) of grass carp muscle proteins during cold storage $\left(4{ }^{\circ} \mathrm{C}\right)$. Different letters indicate significant differences among the samples obtained at different storage times $(P<0.05)$.

\section{Surface hydrophobicity}

As shown in Figure 3A, the hydrophobicity index of grass carp muscle protein reached to 20416 at the 4th day from 11751 for fresh sample, undergoing a remarkable increase of $(\mathrm{P}<0.05)$, which might be due to exposure of hydrophobic groups caused by protein denaturation or degradation. Then the hydrophobicity index declined gradually during the next 6 days, and dropped by $42 \%$ at the 10 th day.

\section{Total SH content}

Total SH content of muscle protein increased slightly 
Table I.- Changes in relative content of proteins corresponding to different bands.

\begin{tabular}{|c|c|c|c|c|c|c|c|c|}
\hline Band No. & MW (kDa) & Maybe & $0 \mathrm{~d}\left(\right.$ IOD $\left.^{\mathrm{a}}\right)$ & 2 d (IOD) & $4 \mathrm{~d}$ (IOD) & $6 \mathrm{~d}$ (IOD) & $8 \mathrm{~d}$ (IOD) & $10 \mathrm{~d}$ (IOD) \\
\hline 1 & 212 & $\mathrm{MHC}^{\mathrm{b}}$ & 264.23 & 250.73 & 166.52 & 164.66 & $\mathrm{ND}^{\mathrm{c}}$ & ND \\
\hline 2 & 180 & & ND & 83.29 & 88.229 & ND & ND & ND \\
\hline 3 & 160 & & ND & ND & ND & 50.11 & ND & ND \\
\hline 4 & 150 & & 238.82 & 150 & 140.1 & 62.582 & ND & ND \\
\hline 5 & 120 & & 252.74 & ND & 170.08 & ND & ND & ND \\
\hline 6 & 96 & $\alpha$-Actinin & 206.57 & 81.282 & 90.387 & 114.63 & ND & ND \\
\hline 7 & 90 & & ND & ND & ND & ND & 128.8 & 86.277 \\
\hline 8 & 87 & & 126.93 & ND & ND & ND & ND & ND \\
\hline 9 & 75 & & 219.07 & 109.72 & 123.42 & 64.845 & ND & ND \\
\hline 10 & 66 & Fimbrin & 210.67 & 115.02 & ND & ND & 98.594 & 86.144 \\
\hline 11 & 59 & & 148.21 & 69.08 & 79.111 & 55.777 & 82.056 & 84.346 \\
\hline 12 & 50 & & 211.23 & 144.31 & 142.82 & 120 & 157.35 & 129.82 \\
\hline 13 & 42 & Actin & 567.47 & 355.13 & 347.66 & 270.33 & 278.99 & 211.93 \\
\hline 14 & 38 & & 340.43 & 282 & 293.98 & 242.14 & 290.53 & 227.14 \\
\hline 15 & 36 & & ND & 134.85 & ND & 90.323 & 200.54 & 142.79 \\
\hline 16 & 35 & Tropomyosin & 425.1 & 170.37 & 188.8 & 170.01 & ND & 136.7 \\
\hline 17 & 34 & & ND & 135.88 & ND & 99.356 & 154.26 & 105.32 \\
\hline 18 & 33 & & ND & 87.649 & 101.32 & 63.311 & 104.7 & ND \\
\hline 19 & 31 & & 188.89 & 113.36 & 128.7 & ND & ND & ND \\
\hline 20 & 29 & & ND & ND & ND & 80.159 & ND & ND \\
\hline 21 & 27 & & 158.66 & 95.919 & 100.15 & 82.081 & ND & ND \\
\hline 22 & 25 & $\mathrm{MLC}^{\mathrm{d}}$ & 156.01 & 108.06 & 111.93 & 89.24 & 102.26 & 181.02 \\
\hline 24 & 23 & & 132.03 & 94.025 & 101.58 & 82.007 & ND & ND \\
\hline 25 & 22 & & 166.85 & 112.44 & 117.88 & 87.094 & ND & ND \\
\hline 26 & 18 & MLC2 & 318.21 & 218.07 & 192.43 & 201.96 & ND & ND \\
\hline 27 & 15 & MLC3 & 343.14 & 258.3 & 275.75 & 280.77 & ND & ND \\
\hline Sum & & & 4675.3 & 3168.4 & 2960.8 & 2471.4 & 1598.1 & 1391.5 \\
\hline
\end{tabular}

a, integrated optical density; ${ }^{\text {b, }}$ myosin heavy chain; ${ }^{c}$, not detected; ${ }^{d}$ myosin light chain.

after 2 days storage, and dramatically increased $43 \%$ to $57.53 \mathrm{~mol} / \mathrm{g}$ at the 4 th day $(P<0.05)$, then decreased gradually up to 10 days (Fig. 3B). This was in accord with the trend of surface hydrophobicity (Fig. 3A), confirming the results of Hill et al. (1982) that oxidation of SH residues affect protein's surface hydrophobicity.

\section{$\mathrm{Ca}^{2+}$-ATPase activity}

Myosin accounts for $50 \%$ of myofibrillar protein and the globular heads of myosin are responsible for the activity of $\mathrm{Ca}^{2+}$-ATPase (Godiksen et al., 2003). In present study, the initial value of $\mathrm{Ca}^{2+}$-ATPase activity was 0.151 $\mu \mathrm{g} \mathrm{Pi} / \mathrm{mg}$ protein/min and decreased gradually (Fig. 3C). Benjakul et al. (2003) reported that the $\mathrm{Ca}^{2+}$-ATPase activity of fishes muscle decreased during frozen storage because of protein denaturation and tissue disruption. After 4 days of cold storage $\left(4^{\circ} \mathrm{C}\right)$, the decrease of activity was significant $(P<0.05)$, corresponding to the denaturation of myosin, which agreed with the results of IOD of protein bands (Table I).

\section{DISCUSSION}

From our results of changes in relative content of grass carp muscle protein fractions, we speculate that the texture of grass carp fillets would begin to change after 4 days of cold storage, and significant changes would take place since or after 6 days. Myofibrillar protein is the most important protein in fish muscle, Jasra et al. (2001) found that enzymatic proteolysis of fish meat during postmortem storage induced the disruption of the structure of the myofibrillar proteins. Lin et al. (2012) identified that the special textural characteristics of grass carp correlated with higher content of myofibrillar protein, and the mastication properties of crisp grass carp muscle were positively correlated with more interstitial material (sarcoplasmic proteins) in fish. According to Sriket et al. (2007), collagen protein is the major component of myostromin protein and has a pronounced effect on hardness and cohesiveness of shrimp meat. However, further studies would be focused on the relationship of change in protein fraction and the texture of grass carp fillets. 
SDS-PAGE analysis further corroborated existing evidence that muscle protein of grass carp gradually degraded during cold storage. As shown in Table I, the integrated optical density of myosin (MHC, tropomyosin, MLC) decreased significantly since or after 4 days of cold storage at $4{ }^{\circ} \mathrm{C}(P<0.05)$, suggesting the start of significant changes in this type of protein fraction. These results was consistent to other previous reports (Bonnal et al., 2001; Nelson, 1994; Lin et al., 2012).

During cold storage, the protein surface hydrophobicity increased $74 \%$ at the 4 th day, then declined gradually during the next 6 days (Fig. 3A). Which was similar to reports of Roura et al. (1992) and Benjakul et al. (1997), in which the surface hydrophobicity of fish proteins increased substantially during the first 2-3 days of iced storage. Change of surface hydrophobicity reflects conformational change of proteins, and the increase of surface hydrophobicity could be interpreted as an exposure of the interior of the molecule because of protein denaturation or degradation, and the subsequently decreased surface hydrophobicity was likely to be associated with refolding and aggregation of the resulting proteins (Roura et al., 1992; Benjakul et al., 1997).

Based on data from previous literatures (Hayakawa and Nakai, 1985), the increase in total SH content might be due to that some proteins (such as myofibrillar protein) exposed the embedded original $\mathrm{SH}$ group because of conformational changes and degradation, or partial protein oligomers released free $\mathrm{SH}$ group by depolymerization, and the decrease in total $\mathrm{SH}$ group might be caused by formation of disulfide bonds through oxidation of $\mathrm{SH}$ groups. Besides, change trend of some proteins such as myosin was essentially in agreement with the result of $\mathrm{Ca}^{2+}$ ATPase activity assay, indicating the protein denaturation and tissue disruption of grass carp had been happening all the period of cold storage.

\section{CONCLUSIONS}

This study revealed that muscle proteins of grass carp were always subject to degradation and conformational changes during the whole process of cold storage at $4^{\circ} \mathrm{C}$, but significant changes in the relative contents of sarcoplasmicand myofibrillar proteins, SDS-PAGE fingerprints took place after 6 days of storage. Proteins with high MW were easily degraded and the relatively low MW proteins were relatively stable but could not avoid degradation during cold storage period. $\mathrm{Ca}^{2+}$ ATPase of muscle decreased gradually, corresponding to the gradual protein denaturation. Besides, Protein's surface hydrophobicity and total SH content increased at the first 4 days of storage and then decreased gradually up to 10 days. So it could be speculated that the key time point for cold storage of grass carp is approximately 4-6 days. Our results provided some new evidence for that the fish spoilage are related to gradual degradation of muscle proteins during cold storage, and would help to predict quality changes, optimize the storage management and reduce the economic losses of freshwater fish during cold storage. While further investigation in identification of specific proteins by proteomics method was needed.

\section{ACKNOWLEDGEMENTS}

This work was supported by the National Natural Science Foundation of China (31571867, 31201427), Natural Science Foundation of Hunan Province (2017JJ2270), and the scientific research project of the Hunan Provincial Education Department (17B016, 17C0059).

\section{Statement of conflict of interest}

The authors declare that there is no conflict of interests regarding the publication of this article.

\section{REFERENCES}

Benjakul, S., Visessanguan, W., Thongkaew, C. and Tanaka, M., 2003. Comparative study on physicochemical changes of muscle proteins from some tropical fish during frozen storage. Fd. Res. Int., 36: 787-795. https://doi.org/10.1016/S09639969(03)00073-5

Benjakul, S., Seymour, T.A. and Morrissey, M.T., 1997. Physieoehemieal changes in pacific whiting muscle proteins during iced storage[J]. J. Fd. Sci., 62: 729733. https://doi.org/10.1111/j.1365-2621.1997. tb15445.x

Binsi, P.K., Shamasundar, B.A and Dileep, A.O., 2003. Physico-chemical and functional properties of proteins from green mussel (Perna viridis) during ice storage. J. Sci. Fd. Agric., 87: 245-254. https:// doi.org/10.1002/jsfa.2706

Bonnal, C., Raynaud, F., Astier, C., Lebart, M.C., Marcilhac, A., Covers, D., Corraze, G., Gelineau, A., Fleurence, J. and Roustan, C., 2001. Postmortem degradation of white fish skeletal muscle (sea bass, Dicentrarchus labrax): Fat diet effects on in situ dystrophin proteolysis during the prerigor stage. Mar. Biotechnol., 3: 172-180. https://doi. org/10.1007/s101260000059

Chen, T.Y. and Hwang, D.F., 2002. Electrophoretic identification of muscle proteins in 7 puffer species. J. Fd. Sci., 67: 936-942. https://doi. org/10.1111/j.1365-2621.2002.tb09431.x

Godiksen, H., Morzel, M., Hylding, G. and Jessen, 
F., 2009. Contribution of cathepsins B, L and D tomuscle protein profiles correlated with texture in rainbow trout (Oncorhynchus mykiss). Fd. Chem., 113: 889-896. https://doi.org/10.1016/j. foodchem.2008.08.012

Hamoir, G., 1955. Fish proteins. In: Advances in protein chemistry (eds. C. Anfinsen, J. Edsall, F. Richards and D. Eisenberg). Academic Press, New York, USA, pp. 227-288.

Hayakawa, S. and Nakai, S., 1985. Contribution of hydrophobicity, net charge and sulfhydryl groups to thermal properties of ovalbumin. Can. Inst. Fd. Sci. Technol. J., 18: 290-295. https://doi.org/10.1016/ S0315-5463(85)71960-8

Hill, A.R., Irvine, D.M. and Bullock, D.H., 1982. Precipitation and recovery of whey proteins: A review. Can. Inst. Fd. Sci. Technol. J., 15: 155-160. https://doi.org/10.1016/S0315-5463(82)72529-5

Hong, H., Luo, Y., Zhu, S. and Shen, H., 2012. Establishment of quality predictive models for bighead carp (Aristichthys nobilis) fillets during storage at different temperatures. Int. J. Fd. Sci. Technol., 47: 488-494. https://doi.org/10.1111/ j.1365-2621.2011.02868.x

Jasra, S.K., Jarsa, P.K. and Talesara, C.L., 2001. Myofibrillar protein degradation of carp (Labeo rohita) muscle after post-mortem unfrozen and frozen storage. J. Sci. Fd. Agric., 81: 519-524. https://doi.org/10.1002/jsfa.841

Kjaersgård, I.V. and Jessen, F., 2003. Proteome analysis elucidating post-mortem changes in cod (Gadus morhua) muscle proteins. J. Agric. Fd. Chem., 51: 3985-3991. https://doi.org/10.1021/jf0340097

Lin, W., Zeng, Q. Zhu, Z. and Song, G., 2012. Relation between protein characteristics and TPA texture characteristics of crisp grass carp (Ctenopharyngodon Idellus C. ET V) and grass carp (Ctenopharyngodon Idellus). J. Texture Stud., 43: 1-11. https://doi.org/10.1111/j.17454603.2011.00311.x

Lone, G. and Hans, H.H., 1996. Microbiological spoilage of fish and fish products. Int. J. Fd. Microbiol., 33: 121-137. https://doi.org/10.1016/01681605(96)01134-8

Magdalena, M. and Krzysztof, S., 2007. Changes in protein fractions of rainbow trout (Oncorhynchus mykiss) gravads during production and storage. $F d$. Chem., 104: 1006-1013. https://doi.org/10.1016/j. foodchem.2007.01.007

Moral, A., Morales, J., Ruiz-Capollas, C. and Montero, P., 2002. Muscle protein solubility of some cephalopods (pota and octopus) during frozen storage. J. Sci. Fd. Agric., 82: 663-668. https://doi. org/10.1002/jsfa.1088

Nelson, J.S., 1994. Fishes of the world, $3^{\text {rd }}$ ed. John Wiley and Sons Inc., New York.

Niaz, B., Zahoor, T. and Randhawa, M.A., 2017. Isolation of Lactoferrin from camel milk through fast protein liquid chromatography and its antagonistic activity against Escherichia coli and Staphylococcus aureus. Pakistan J. Zool., 49: :1307-1313. http://dx.doi.org/10.17582/journal. pjz/2017.49.4.1307.1313

Ohnishi, S.T. and Barra, J.K., 1978. A simplified method of quantitating protein using the biuret and phenol reagents. Analyt. Biochem., 86: 193-200. https:// doi.org/10.1016/0003-2697(78)90334-2

Reddish, J.M., St-Pierre, N., Nichols, A., GreenChurch, K. and Wick, M., 2008. Proteomic analysis of proteins associated with body mass and length in yellow perch, Perca flavescens. Proteomics, 8: 2333-2343. https://doi.org/10.1002/ pmic. 200700533

Roura, S.J., Saavedra, J.P., Truco, R.E. and Crupkin, M., 1992. Conformational changes in actomyosin from post-spawned hake stored on ice.J.Fd.Sci., 57: 11091111. https://doi.org/10.1111/j.1365-2621.1992. tb11274.x

Shi, C., Cui, J., Lu, H., Shen, H. and Luo, Y., 2012. Changes in iogenic amines of silver carp (Hypophthalmichthys molitrix) fillets stored at different temperatures and their relation to total volatile base nitrogen, microbiological and sensory score. J. Sci. Fd. Agric., 92: 3079-3084. https://doi. org/10.1002/jsfa.5729

Sikorski, Z.E. and Kołakowska, A., 1995. Changes in proteins in frozen stored fish. In: Seafood proteins (eds. Z.E. Sikorski, B.S. Pan and F. Shahidi). Springer, New York, USA, pp. 99-112.

Sriket, P., Benjakul, S., Visessanguan, W. and Kijroongrojana, K., 2007. Comparative studies on chemical composition and thermal properties of black tiger shrimp (Penaeus monodon) and white shrimp (Penaeus vannamei) meats. Fd. Chem., 103: 1199-1207. https://doi.org/10.1016/j. foodchem.2006.10.039

Tang, Q.Y. and Zhang, C.X., 2013. Data Processing System (DPS) software with experimental design, statistical analysis and data mining developed for use in entomological research. Insect Sci., 20: $254-260$. https://doi.org/10.1111/j.17447917.2012.01519.x

Zhang, Y.M., Lua, H.M. and Levin, R.E., 2003. Enhanced storage-life of fresh haddock fillets with stabilized sodium chlorite in ice. Fd. Microbiol., 20: 87-90. https://doi.org/10.1016/S0740-0020(02)00089-8 